\title{
SND1 Gene
}

National Cancer Institute

\section{Source}

National Cancer Institute. SND1 Gene. NCI Thesaurus. Code C96331.

This gene plays a role in both transcriptional regulation and RNA interference. 